\title{
Airway Management in Patients with Tracheobronchial Mass: Challenges and Solutions
}

\section{Trakeobronşiyal Kitlesi Olan Hastalarda Havayolu Yönetimi: Zorluklarve}

\section{Çözümler}

\author{
Levent Dalar'1, Kemal Tolga Saraçoğlu² ${ }^{2}$ Ayten Saraçoğlu ${ }^{3}$
}

1 İstanbul Bilim Üniversitesi Tıp Fakültesi ,Gögüs Hastalıkları Anabilim Dalı, İstanbul, Türkiye

2Sağlık Bilimleri Üniversitesi Tıp Fakültesi, Derice Eğitim ve Araștırma Hastanesi, Anesteziyoloji Ve Reanimasyon Kliniği, Kocaeli, Türkiye 3 Marmara Üniversitesi Tıp Fakültesi, Anesteziyoloji Ve Reanimasyon Anabilim Dalı, İstanbul, Türkiye

To the Editor,

The complication rate due to tracheobronchial mass resections is not frequent but has serious morbidity. In a study involving 901 patients, the postoperative complication rate was determined as $18.2 \%$ (1). Failure of the anastomosis, tracheo innominate fistula, laryngeal edema, wound infection and glottic dysfunction are the commonly reported complications (2).

Challenges for anesthesiologists include the difficulties for coping with central airway obstruction, the management of patients with comorbidities and sharing an airway that can be easily compromised. Total airway obstruction can also appear suddenly. Many forms of obstructive airway disease are accompanied by superior vena cava obstruction, cardiovascular disease, pulmonary sepsis or advanced neoplastic disease (3).

On the other hand, nowadays endoscopic laser applications take place in the treatment of laryngeal pathologies. During the procedure, minimal bleeding, edema and tissue reaction occur. Being minimally invasive and time saving, the advantages of laser excisions include preservation of surrounding structures and normal tissues (4). The recovery is potentially faster with rapid healing and less postop pain.

Figure 1 represents a bronchoscopic view of a central mass which covers both main bronchi and completely obstructs the distal tip of the trachea. The patient was 62-year-old, heavy smoker male with chronic obstructive airway disease. In the last few months, breathlessness has progressively increased and the patient underwent mass excision with the diode laser-assisted approach (Figure 2). During bronchoscopy, it was revealed that the mass extended from the entrance of right lower lobe to

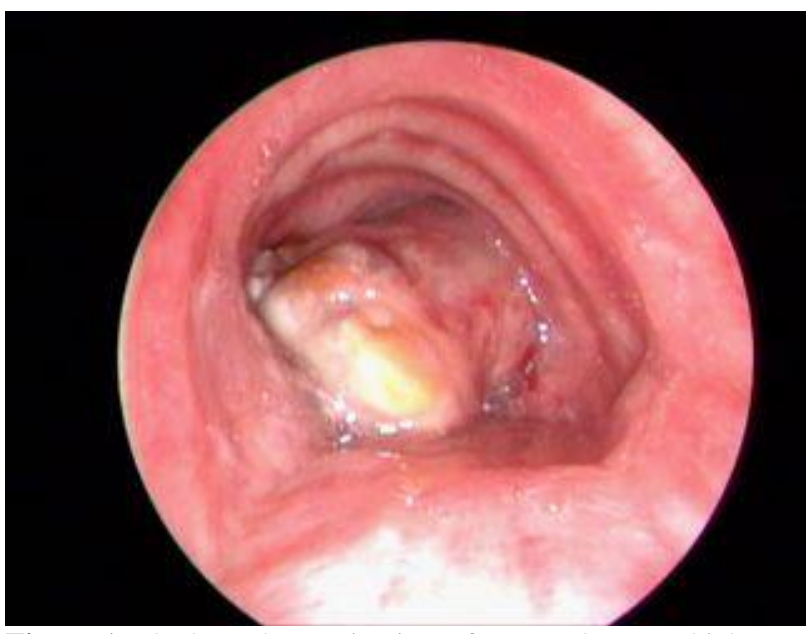

Figure 1. The bronchoscopic view of a central mass which covers both main bronchi and completely obstructs the distal tip of the trachea

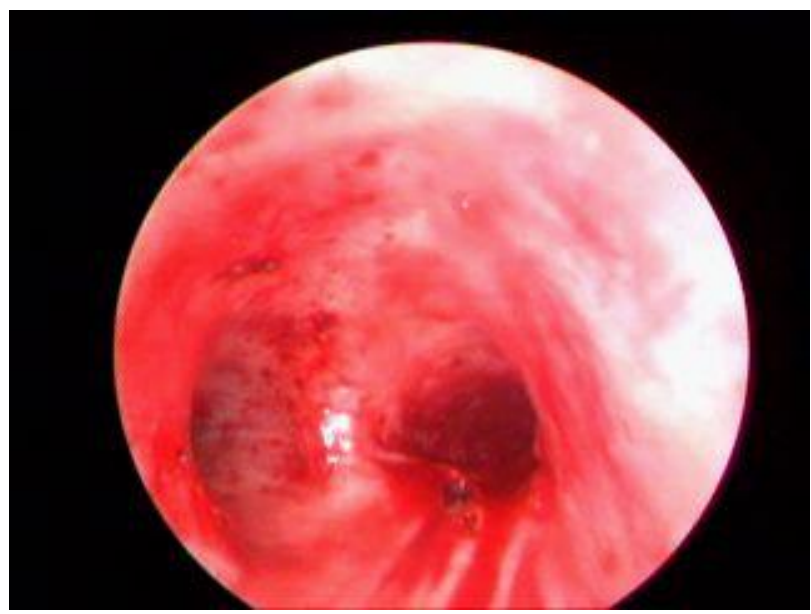

Figure 2.The bronchoscopic view of trachea following mass excision with the diodelaser-assisted minimal invasive approach.

the trachea. After removal of the mass, significant improvement was observed in the symptoms and the pathology was reported as squamous cell carcinoma. 
It should also be emphasized that laser airway surgery is a procedure that requires demanding effective cooperation among all members of staff involved. Since the majority of these patients have various levels of airway obstruction, sedative premedication is almost always contraindicated.

It should be applied considering the risks and benefits. Especially in pediatric patients anticholinergics such as atropine or glycopyrrolate are used to reduce the volume of saliva secretions and to prevent bradycardia which may develop following inhalational anesthesia. A spontaneously breathing technique has been found efficacious and safe with few complications (5). A high flow of oxygen and air mixture is required because of the entrained surrounding air. Nitrous oxide should be avoided as it supports combustion.

In conclusion, total airway obstruction, accompanying comorbidities and sharing an airway are the most frequent challenges of airway management during the exision of tracheobronchial mass. Diode Laser-assisted approach is a minimally invasive and time saving procedure for the resection of such masses. Therefore this endobronchial technique can be a solution for limiting the perioperative complications and improving the patient safety.

The authors state no conflict of interest

Iletişim / Correspondence:

Dr. Ayten Saraçoğlu

Marmara Üniversitesi Tıp Fakültesi, Anesteziyoloji Ve Reanimasyon Anabilim Dalı, İstanbul, Türkiye

E-mail: anesthesiayten@gmail.com

Başvuru Tarihi:04.11.2017

Kabul Tarihi:23.01.2018 